\title{
PENGARUH KONVERGENSI IFRS DAN KEPEMILIKAN ASING TERHADAP TIMELY LOSS RECOGNITION
}

\author{
Liliek Nur Sulistiyowati $^{1)}$,Robby Sandhi Dessyarti ${ }^{2)}$, Adi Gunanto ${ }^{3)}$ \\ Universitas PGRI Madiun \\ liliek1702@gmail.com \\ robbeyvan@gmail.com \\ adigunanto1994@gmail.com
}

\begin{abstract}
This research is intended to analyzeinfluence of convergence of International Financial Reporting Standard (IFRS) and foreign ownership to Timely Loss Recognition (TLR) at trade and service company listed in Bursa Efek Indonesia (BEI). This research comparing between before and after the IFRS convergence of the level loss recognition and see whether there is an increase in therecognition of a loss on time with the presence of foreign ownership within the company.Researchers used four control variables, namely firm size, profitability, leverage, and audit quality. TLR is measured by the ratio of Large Negative Net Income.This research used purposive sampling method at companies listed on BEI from 2014 until 2016, there are 13 samples and tested by using linear regression. The results of this research indicate thatthere was an influence between IFRS convergence and foreign ownership of TLR. Control variable, leverage variable and audit quality indicatesignificant influence. This research has once again indicatethat the application of IFRS has an impact on improving the quality of accounting information and the demand for timely recognition of losses in less than stackholder financial statements. Keywords: Timely Loss Recognition, IFRS Convergence, Foreign Ownership
\end{abstract}

\section{ABSTRAK}

Penelitian ini dilakukan untuk mengetahui pengaruh konvergensi International Financial Reporting Standard (IFRS) dan kepemilikan asing terhadap Timely Loss Recognition (TLR) pada perusahaan trade and service yang terdaftar di Bursa Efek Indonesia (BEI). Penelitian ini membandingkan tingkat pengakuan rugi antara sebelum dengan sesudah konvergensi IFRS dan melihat apakah terdapat peningkatan pada pengakuan rugi tepat waktu dengan adanya kepemilikan asing di dalam perusahaan. Selain kedua variabel tersebut, peneliti menggunakan empat variabel kontrol, yaitu ukuran perusahaan, profitabilitas, leverage, dan kualitas audit. TLR diukur dengan rasio Large Negative Net Income. Pengambilan sampel dilakukan dengan metode purposive sampling pada perusahaan yang terdaftar di BEI dari tahun 2014 sampai dengan tahun 2016 dan diperolah 13 sampel yang diuji dengan menggunakan regresi linier. Hasil penelitian menunjukkan terdapat pengaruh antara konvergensi IFRS dan kepemilikan asing terhadap TLR. Sedangkan pada variabel kontrol, variabel leverage dan kualitas audit menunjukkan pengaruh signifikan. Penelitian ini sekali lagi menunjukkan bahwa penerapan IFRS sudah memberi dampak pada peningkatan kualitas informasi akuntansi dan permintaan akan kebutuhan pengakuan rugi yang tepat waktu pada laporan keuangan yang masih kurang dari stackholder.

Kata Kunci: Timely Loss Recognition, Konvergensi IFRS, Kepemilikan Asing

\section{A. PENDAHULUAN}

Terhitung mulai 1 Januari

2012 semua perusahaan terbuka

(Go Public) di Indonesia wajib

menyajikan laporan keuanganya sesuai dengan Standar Akuntansi

Keuangan (SAK) yang sudah

konvergen dengan International

Financial Reporting Standard

(IFRS), (Suprihatin dan 
Tresnaningsih, 2013). Ikatan Akuntan Indonesia (IAI) sebagai organisasi yang berwenang dalam membuat standar akuntansi di Indonesia telah melakukan proses adopsi standar akuntansi internasional, sehingga diharapkan dapat menghasilkan laporan keuangan yang dapat dibandingkan dengan negaranegara lain. Dewasa ini Indonesia pun dituntut untuk menerapkan standar Internasional, sebagai salah satu negara yang tergabung dalam Group of 20 Leaders (G20) dan anggota International Federation of Accountants (IFAC).

Menurut Zeghal et al. (2012). Munculnya International Financial Reporting Standard (IFRS) yang diterbitkan International Accounting Standard Board (IASB) sebagai organisasi internasional yang independen menjadi solusi atas kebutuhan laporan keuangan yang berkualitas. International Accounting Standard Board (IASB) mengembangkan dan membuat standar baru yang menjanjikan kualitas yang lebih baik pada laporan keuangan. Dalam rerangka konseptual International Financial Reporting Standard (IFRS), terdapat dua macam kualitas yang dapat terpenuhi dengan penerapan standar baru, yaitu kualitas primer dan kualitas sekunder. Kualitas primer terdiri dari relevan dan Faithfull Representation (representasi sebenarnya), sedangkan kualitas sekunder terdiri dari Comparability (dapat dibandingkan), Verifiability (dapat diverifikasi), Timeliness (ketepatwaktuan), dan Understandability (dapat dipahami). Sedangkan yang terakhir adalah tujuan kebutuhan khusus merupakan gabungan dari tujuan perlindungan publik dan tujuan informatif. Apa yang harus diungkapkan kepada publik dibatasi dengan apa yang dipandang bermanfaat bagi pemakai untuk tujuan pengawasan yang harus 
disampaikan kepada badan

pengawas berdasarkan Pasal 2

PP No. 24 Tahun 1998 tentang

Informasi Keuangan Tahunan

$\underline{\text { Perusahaan }}$

(PP

24/1998) sebagaimana

telah

diubah dengan (PP No. 64 Tahun

1999) tentang Perubahan Atas

(PP No. 24 Tahun 1998) tentang

Informasi Keuangan Tahunan

Perusahaan (PP 64/1999) dan

formulir-formulir yang menuntut

pengungkapan secara rinci.

(Lembaran Negara Republik

Indonesia, 1999).

Sebagai salah satu

komponen kualitas laporan

keuangan dan kualitas laba,

banyak penelitian sudah

dilakukan terkait Timely Loss

Recognation (TLR). Barth et al.

(2008), Outa (2011) dan Chua et

al. (2012) menyatakan terdapat

peningkatan TLR pada

perusahaan yang menerapkan

IFRS yang mengindikasikan

adanya peningkatan kualitas

informasi. Sedangkan Aflatooni

\& Mokarami (2013) menemukan

adanya penurunan Timely Loss
Recognation (TLR) pada

perusahaan yang melakukan

manajemen laba yang

berimplikasi pada semakin

rendah kualitas laba, maka

semakin rendah pula Timely Loss

Recognation (TLR). Penelitian

lain terkait Timely Loss

Recognation (TLR) juga banyak

dilakukan seperti pengaruh

penerapan International

Financial Reporting Standard

(IFRS) pada Timely Loss

Recognation (TLR). Beberapa

penelitian berfokus pada

pengujian apakah terdapat

perbaikan kualitas pelaporan dan

kualitas informasi setelah

diterapkannya IFRS. Dari hasil

penelitian sebelumnya, beberapa

penelitian menyatakan terdapat

peningkatan kualitas laporan

keuangan setelah menerapkan

IFRS seperti Barth et al. (2008),

Chua et al. (2012), Outa (2011),

dan Arum (2013).

Namun ada juga penelitian

yang menyatakan tidak ada

peningkatan kualitas antara

sebelum dengan sesudah 
penerapan IFRS seperti

penelitian yang dilakukan oleh Paglietti (2009), Brauer et al. (2011), dan Sianipar \& Marsono (2013). Dengan ditetapkannya tahun 2005 sebagai periode Mandatory Adoption di Eropa, banyak negara-negara besar di Eropa telah menerapkan IFRS sebagai standar akuntansi keuangan seperti Inggris, Prancis, Jerman, Yunani, Italia, dan Spanyol. Beberapa penelitian lain juga menyatakan hal yang bertentangan dengan penelitian sebelumnya. Penelitian seperti: Brauer et al. (2011), Paglietti (2009), Arum (2013), Sun et al. (2011), Ball et al. (2008), Ball et al. (2000), dan Sianipar \& Marsono (2013) menyatakan penerapan IFRS tidak berpengaruh pada Timely Loss Recognation walaupun kualitas laporan keuangan lain meningkat seperti relevansi nilai dan penurunan manajemen laba.

\section{B. Rumusan Masalah}

Berdasarkan latar belakang penelitian yang telah diuraikan sebelumnya, maka peneliti merumuskan masalah yang hendak diteliti sebagai berikut :

1. Apakah Standar Konvergensi IFRS berpengaruh signifikan terhadap Timely Loss Recognition (TLR) ?

2. Apakah Kepemilikan Asing berpengaruh signifikan pada Timely Loss Recognition (TLR)?

3. Apakah Standar Konvergensi IFRS, dan Kepemilikan Asing berpengaruh signifikan terhadap Timely Loss Recognition (TLR) ?

\section{Tujuan Penelitian}

Berdasarkan rumusan masalah di atas, maka tujuan dari penelitian ini adalah untuk membuktikan secara empiris bahwa :

1. Penerapan standar konvergensi IFRS berpengaruh signifikan 
terhadap Timely Loss

Recognition (TLR).

2. Kepemilikan

Asing berpengaruh signifikan terhadap Timely Loss Recognition (TLR).

3. Standar Konvergensi IFRS, dan Kepemilikan Asing berpengaruh signifikan terhadap Timely Loss Recognition (TLR).

\section{Agency Theory}

Agency Theory atau teori keagenan merupakan suatu teori yang mengemukakan adanya kesenjangan atau asimetri kepentingan antara agen dengan principal (Hill \& Jones, 1992). Agen adalah pihak yang diberi tanggungjawab oleh principal untuk mengelola perusahaan, sedangkan principal merupakan pihak yang memberi kepercayaan kepada agen untuk mengelola dana yang mereka berikan. Sebagai pihak yang diberi tanggung jawab mengelola perusahaan, agen memiliki kewajiban untuk menyampaikan laporan baik mengenai kinerja perusahaan, maupun pertumbuhan perusahaan yang terlihat dari laporan keuangan. Dengan kata lain, agen memiliki pengetahuan dan informasi lebih banyak tentang kondisi perusahaan dibandingkan principal, dan hal inilah yang memicu konflik antara agen dan principal yang sering disebut konflik keagenan.

\section{E. Kerangka Pemikiran}

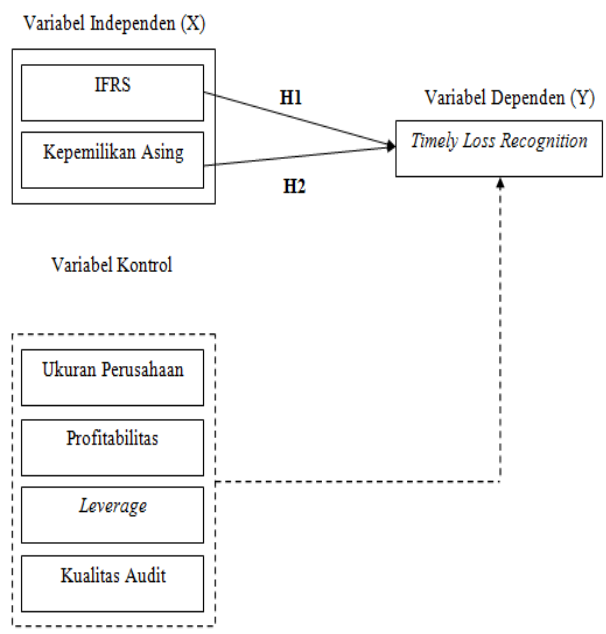

F. Perumusan Hipotesa

a. Pengaruh International

Financial Reporting Standard (IFRS) terhadap Timely Loss Recognition (TLR)

Barth et al. (2008), dan Chua et al. (2012) menemukan 
adanya pengakuan rugi yang

lebih tepat waktu setelah

penerapan International

Financial Reporting

Standard (IFRS). Peneliti

berpendapat bahwa

konvergensi International

Financial Reporting

Standard (IFRS) dapat

meningkatkan kualitas

laporan keuangan dengan

pengakuan rugi yang lebih

tepat waktu, sehingga

hipotesis dirumuskan sebagai

berikut:

$\mathrm{H}_{1}$ : IFRS

berpengaruh

signifikan pada

peningkatan

Timely Loss

Recognition

(TLR).

b. Pengaruh Kepemilikan

Asing terhadap Timely

Loss Recognition (TLR).

Chua et al. (2012)

menemukan bahwa

investasi asing meningkat

pada perusahaan setelah menerapkan International

Financial Reporting

Standard

(IFRS).

Sedangkan Penelitian

Sianipar \& Marsono, (2013) yang menyatakan

bahwa perusahaan dengan kepemilikan asing akan cenderung mengungkapkan kerugian tepat waktu yang lebih awal karena kepemilikan asing dalam perusahaan merupakan pihak yang dianggap concern terhadap

pengungkapan

pertanggungjawaban

perusahaan. Sehingga

Hipotesis dirumuskan

sebagai berikut :

$\mathbf{H}_{2}$ : Kepmilikan

Asing

berpengaruh

signifikan pada

peningkatan

Timely Loss

Recognition

(TLR).

c. Pengaruh International 


\begin{tabular}{lrr} 
Financial & \multicolumn{2}{r}{ Reporting } \\
Standard (IFRS) & dan \\
Kepemilikan & Asing \\
terhadap & Timely & Loss \\
Recognition & (TLR). &
\end{tabular}

Sejalan dengan penelitian yang dilakukan di luar negeri untuk menguji dampak penerapan IFRS terhadap struktur kepemilikan asing sudah banyak dilakukan. Antara lain, Defond et al. (2011) dan Chua et al. (2012) menemukan bahwa investasi asing meningkat pada perusahaan setelah menerapkan IFRS. Sedangkan di Indonesia, belum ada penelitian yang dilakukan untuk menguji apakah penerapan IFRS benar-benar memberikan manfaat dalam peningkatan arus investasi global yang ditunjukkan dengan adanya kenaikan tingkat kepemilikan asing di Indonesia. Sehingga Hipotesis dirumuskan sebagai berikut :

$\mathrm{H}_{3}$ : International Financial Reporting Standard (IFRS) dan Kepemilikan Asing berpengaruh signifikan pada Timely Loss Recognition (TLR).

\section{G. Instrumen Penelitian}

Dalam penelitian ini digunakan beberapa variabel. Variabel penelitian sendiri merupakan segala sesuatu yang berbentuk apa saja yang ditetapkan untuk dipelajari sehingga dapat diperoleh informasi untuk kemudian ditarik kesimpulan (Sugiyono, 2013). Penelitian ini menggunakan tiga macam variabel, yang terdiri dari (a) satu variabel dependen, (b) dua variabel independen, dan (c) empat variabel kontrol. 


\section{H. Teknik Analisis Data}

\section{Uji Normalitas}

One-Sample Kolmogorov-Smirnov Test

\begin{tabular}{llr}
\hline & & $\begin{array}{r}\text { Unstandardized } \\
\text { Predicted Value }\end{array}$ \\
\hline $\mathrm{N}$ & & 39 \\
Normal Parameters & Mean &, 4358974 \\
& Std. Deviation &, 15794483 \\
Most Extreme Differences & Absolute &, 100 \\
& Positive &, 079 \\
& Negative &,- 100 \\
Kolmogorov-Smirnov Z & &, 624 \\
Asymp. Sig. (2-tailed) & &, 831 \\
\hline
\end{tabular}

a. Test distribution is Normal.

b. Calculated from data.

Sumber : Hasil Statistical Product and service Solutions SPSS V.18

Berdasarkan pengujian Asymp. Sig (2-tailed) $0.831>0,05$

normalitas di atas didapatkan nilai hal ini mengindikasikan bahwa Kolmogorov- Smirnov $\mathrm{Z}$ sebesar berdasarkan uji tersebut dinyatakan 0,624 dengan nilai Asymp. Sig (2- data berdistribusi normal. tailed) sebesar 0,831. Karena

\section{Multikolinieritas}

\begin{tabular}{|c|c|c|c|}
\hline \multirow{3}{*}{ Model } & \multicolumn{3}{|c|}{ Coefficients $^{\mathrm{a}}$} \\
\hline & & \multicolumn{2}{|c|}{ Collinearity Statistics } \\
\hline & & Tolerance & VIF \\
\hline \multirow[t]{7}{*}{1} & (Constant) & & \\
\hline & IFRS & ,858 & 1,166 \\
\hline & Kepemilikan_Asing & ,930 & 1,075 \\
\hline & LNSIZE & ,749 & 1,335 \\
\hline & PROFIT & ,355 & 1,815 \\
\hline & LEVER &, 721 & 1,387 \\
\hline & AUD & ,277 & 1,612 \\
\hline
\end{tabular}

a. Dependent Variable: Timely_Loss_Recognition

Sumber : Hasil Statistical Product and service Solutions SPSS V.18

Hasil uji multikolonieritas perhitungan Variance Inflation Factor terlihat bahwa tidak ada variabel (VIF) juga menunjukkan bahwa tidak independen yang memiliki nilai ada satu variabel independen yang Tolerance kurang dari 0,10 dan hasil memiliki nilai VIF lebih dari 10. 
Maka dapat disimpulkan bahwa diajukan bebas dari multikolonieritas. persamaan model regresi yang

\section{Uji Autokorelasi}

\begin{tabular}{llrrrrr}
\multicolumn{7}{c}{ Model Summary $^{\mathbf{b}}$} \\
\hline Model & $\mathrm{R}$ & R Square & $\begin{array}{c}\text { Adjusted R } \\
\text { Square }\end{array}$ & $\begin{array}{c}\text { Std. Error of the } \\
\text { Estimate }\end{array}$ & $\begin{array}{c}\text { Durbin- } \\
\text { Watson }\end{array}$ \\
\hline 1 &, $480^{\mathrm{a}}$ &, 231 &, 333 & 462 & 1,999 \\
\hline
\end{tabular}

a. Predictors: (Constant), IFRS, Kepemilikan_Asing, LNSIZE, LEVER, PROFIT, AUD

b. Dependent Variable: Timely_Loss_Recognition

Sumber : Hasil Statistical Product and service Solutions SPSS V.18

Nilai Durbin-Watson sebesar $>1,999<1.6044$. Karena nilai D 1,999 dengan jumlah sampel $(\mathrm{N}=$ berada pada $4-\mathrm{dl}<\mathrm{d}<4$ maka 13), dan jumlah variable bebas menghasilkan kesimpulan D berada $(\mathrm{k}=2)$ batas bawah $(\mathrm{dL})=0.7580$ pada (tidak ada autokorelasi dan batas atas $(\mathrm{dU})=1.6044$ negative $)$.

Karena dL $<$ DW $<$ dU yaitu 0.7580

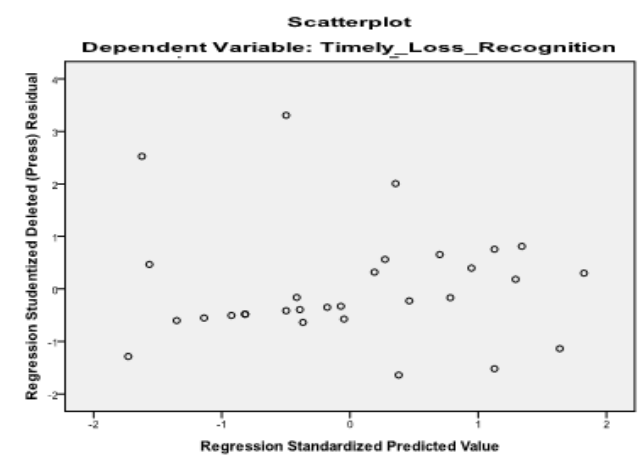

\section{Gambar 4.1 Heterokedastisitas}

Sumber : Hasil Statistical Product and service Solutions SPSS V.18

Berdasarkan gambar diatas dan dibawah angka 0 sumbu Y, maka data pada penelitian ini dapat disimpulkan bahwa data tidak menunjukkan bahwa data menyebar terjadi masalah heteroskedastisitas. dengan pola yang tidak jelas diatas 


\section{Regresi Linier berganda}

\begin{tabular}{llrr}
\multicolumn{4}{c}{ Coefficients $^{\mathbf{a}}$} \\
\hline Model & \multicolumn{3}{c}{ Unstandardized Coefficients } \\
& & B & Std. Error \\
\hline 1 & (Constant) &, 937 & 1,164 \\
& IFRS & 1,617 &, 202 \\
& Kepemilikan_Asing & 1,079 &, 149 \\
& LNSIZE &,- 318 &, 044 \\
& PROFIT &, 692 &, 950 \\
& LEVER &, 957 &, 171 \\
& AUD &, 057 &, 153 \\
\hline \multicolumn{4}{c}{ a. Dependent Variable: Timely_Loss_Recognition } \\
Sumber : Hasil Statistical Product and service Solutions SPSS V.18
\end{tabular}

Berdasarkan perhitungan yang dilakukan dengan menggunakan SPSS Versi 18.0 di atas maka didapat persamaan regresi linier sebagai berikut :

$$
\begin{gathered}
Y=937+1,617 X_{1}+1,079 \times 2- \\
318+692+957+057+\varepsilon,
\end{gathered}
$$

Berdasarkan persamaan regresi tersebut dapat dianalisis pengaruh masing-masing variabel independen terhadap Timely Loss Recognition, yaitu :

a) $\alpha=0,937:$ menunjukkan besarnya pengaruh variabel bebas terhadap variabel terikat, apabila variabel bebas konstant $(X=0)$. Artinya sebelum dipengaruhi oleh International Financial Reporting
Standard (IFRS), Kepemilikan Asing dan Variabel Kontrol Ukuran Perusahaan, Profitabilitas, Leverage serta Kualitas Audit maka besarnya Timely Loss Recognition adalah 0,937 persen.

b) $b_{1}=1,617:$ nilai koefisien regresi $\left(b_{1}\right)$ sebesar 1,617 ; dari $b_{1}$ yang mempunyai nilai 1,617 menunjukkan apabila variabel International Financial Reporting Standard (IFRS) meningkat sebesar 1,617 satu persen, maka Timely Loss Recognition (TLR) akan naik sebesar 1,617 persen dengan asumsi bahwa variabel bebas lainnya adalah konstan.

c) $b_{2}=1,079:$ nilai koefisien regresi $\left(b_{1}\right)$ sebesar 1,079 ; dari $b_{1}$ yang mempunyai nilai 1,079 menunjukkan apabila variabel 
Kepemilikan Asing meningkat sebesar 1,079 satu persen, maka Timely Loss Recognition (TLR) akan naik sebesar 1,079 persen dengan asumsi bahwa variabel bebas lainnya adalah konstan.

d) $b_{3}=-318:$ nilai koefisien regresi $\left(b_{3}\right)$ sebesar -318 : dari $b_{3}$ yang mempunyai nilai -318 menunjukkan apabila variabel Ukuran Perusahaan meningkat sebesar -318 satu persen, maka Timely Loss Recognition (TLR) akan turun sebesar $-3,18$ persen dengan asumsi bahwa variabel bebas lainnya adalah konstan.

e) $b_{4}=692:$ nilai koefisien regresi $\left(b_{4}\right)$ sebesar 692 : dari $b_{4}$ yang mempunyai nilai 692 menunjukkan apabila variabel Profitabilitas meningkat sebesar 692 satu persen, maka Timely Loss Recognition
(TLR) akan naik sebesar 692 persen dengan asumsi bahwa variabel bebas lainnya adalah konstan.

f) $b_{5}=957:$ nilai koefisien regresi $\left(b_{5}\right)$ sebesar $957 \quad$ : dari $b_{5}$ yang mempunyai nilai 957 menunjukkan apabila variabel Leverage meningkat sebesar 957 satu persen, maka Timely Loss Recognition (TLR) akan naik sebesar 957 persen dengan asumsi bahwa variabel bebas lainnya adalah konstan.

g) $b_{6}=057$ : nilai koefisien regresi $\left(b_{6}\right)$ sebesar 057 : dari $\mathrm{b}_{6}$ yang mempunyai nilai 057 menunjukkan apabila variabel Kualitas Audit meningkat sebesar 057 satu persen, maka Timely Loss Recognition (TLR) akan naik sebesar 057 persen dengan asumsi bahwa variabel bebas lainnya adalah konstan.

\section{Uji Statistik t}

\begin{tabular}{|c|c|c|c|c|c|}
\hline \multicolumn{6}{|c|}{ Coefficients $^{\mathrm{a}}$} \\
\hline \multirow[t]{2}{*}{ Model } & \multicolumn{2}{|c|}{$\begin{array}{l}\text { Unstandardized } \\
\text { Coefficients }\end{array}$} & \multirow{2}{*}{$\begin{array}{c}\text { Standardized } \\
\text { Coefficients } \\
\text { Beta }\end{array}$} & \multirow[b]{2}{*}{$\mathrm{t}$} & \multirow[b]{2}{*}{ Sig. } \\
\hline & $\mathrm{B}$ & Std. Error & & & \\
\hline (Constant) & ,937 & 1,164 & & ,805 &, 425 \\
\hline IFRS & 1,617 & ,202 &, 027 & 2,785 & ,039 \\
\hline Kepemilikan_Asing & 1,079 & ,149 &,- 070 & $-1,930$ & 079 \\
\hline LNSIZE &,- 318 & 044 &,- 087 & $-1,585$ &,- 061 \\
\hline PROFIT & ,692 & ,950 & ,398 & ,854 &, 070 \\
\hline LEVER & ,957 &, 171 & ,295 & 1,960 & ,056 \\
\hline AUD &, 057 & ,153 & ,090 &, 730 &, 013 \\
\hline
\end{tabular}


1) Pada variabel International Financial Reporting Standard (IFRS) diperoleh $t_{\text {hitung }}$ sebesar 2,785 dan $t_{\text {tabel }}$ sebesar 1,943 serta didapatkan nilai signifikan sebesar 039. Hal ini menunjukkan bahwa variabel International Financial Reporting Standard (IFRS) secara parsial berpengaruh signifikan terhadap pengungkapan Timely Loss Recognition (TLR).

2) Pada variabel Kepemilikan Asing diperoleh $t_{\text {hitung }}$ sebesar $-1,930$ dan $\mathrm{t}_{\text {tabel }}$ sebesar 1,943 serta didapatkan nilai signifikan sebesar 079 . Hal ini menunjukkan bahwa variabel Kepemilikan Asing secara parsial tidak berpengaruh signifikan terhadap pengungkapan Timely Loss Recognition (TLR).

3) Pada variabel kontrol Ukuran Perusahaan diperoleh $t_{\text {hitung }}$ sebesar $-1,585$ dan $t_{\text {tabel }}$ sebesar 1,943 serta nilai signifikan sebesar -061 .

4) Pada variabel kontrol Profitabilitas diperoleh $t_{\text {hitung }}$ sebesar 0,854 dan $t_{\text {tabel }}$ sebesar 1,943 serta nilai signifikan sebesar 070.

5) Pada variabel kontrol Leverage diperoleh $t_{\text {hitung }}$ sebesar 1,960 dan $t_{\text {tabel }}$ sebesar 1,943 serta nilai signifikan sebesar 056.

6) Pada variabel kontrol Kualitas Audit diperoleh $t_{\text {hitung }}$ sebesar 0,730 dan $t_{\text {tabel }}$ sebesar 1,943 serta nilai signifikan sebesar 013 .

\section{Uji Statistik F}

\begin{tabular}{lccccc}
\multicolumn{7}{c}{ ANOVA $^{\mathbf{b}}$} & & & \\
\hline Model & Sum of Squares & Df & Mean Square & F & Sig. \\
\hline 1 Regression & 3,009 & 6 &, 501 & 2,150 &, $004^{\mathbf{a}}$ \\
Residual & 10,028 & 47 &, 213 & & \\
Total & 13,037 & 53 & & & \\
\hline a. Predictors: (Constant), IFRS, Kepemilikan_Asing, LNSIZE, LEVER, PROFIT, AUD \\
b. Dependent Variable: Timely_Loss_Recognition \\
Sumber : Hasil Statistical Product and service Solutions SPSS V.18
\end{tabular}

Berdasarkan hasil uji statistik $\mathrm{F}$

di atas output regresi menunjukkan $\mathrm{F}_{\text {hitung }}: 2,150$ dan $\mathrm{F}_{\text {tabel }}: 3,05$; berarti $\mathrm{F}_{\text {hitung }}<\mathrm{F}_{\text {tabel }}$ pada tingkat kesalahan $5 \%$ besarnya signifikan (probabilitas) $0,05>0,04(\alpha=5 \%)$ maka $\mathrm{H}_{0}$ ditolak dan $\mathrm{H}_{1}$ diterima, kesimpulannya bahwa variabel International Financial Reporting Standard (IFRS) dan Kepemilikan 
Asing, Ukuran Perusahaan, bersama-sama berpengaruh terhadap Profitabilitas, Leverage dan Kualitas Timely Loss Recognition (TLR).

Audit sebagai variabel kontrol secara

\section{Koefisien Determinasi $\left(\mathbf{R}^{2}\right)$}

\begin{tabular}{|c|c|c|c|c|c|}
\hline \multicolumn{6}{|c|}{ Model Summary } \\
\hline Model & $\mathrm{R}$ & R Square & $\begin{array}{l}\text { Adjusted R } \\
\text { Square }\end{array}$ & $\begin{array}{l}\text { Std. Error of the } \\
\text { Estimate }\end{array}$ & $\begin{array}{l}\text { Durbin- } \\
\text { Watson }\end{array}$ \\
\hline 1 &, $480^{\mathrm{a}}$ & ,231 & ,333 & ,462 & 1,999 \\
\hline
\end{tabular}

Berdasarkan tabel di atas

pada kolom Adjusted $R$ Square, diperoleh nilai koefisien determinasi sebesar 0.333 yang berarti $33,3 \%$ perubahan variabel Timely Loss Recognition dijelaskan oleh perubahan variabel International

\section{Pembahasan}

\section{Pengaruh Konvergensi IFRS terhadap Timely Loss Recognition}

Penelitian ini bertujuan untuk menguji pengaruh konvergensi International Financial Reporting Standard (IFRS) terhadap Timely Loss Recognition (TLR). Variabel TLR diukur dengan rasio Large Negative Net Income (LNEG). Berdasarkan hasil uji t pada tabel 4.8 diketahui bahwa variabel International Financial Reporting
Financial Reporting Standard (IFRS), dan Kepemilikan Asing secara bersama-sama, sedangkan sisanya $66,7 \%$ dijelaskan oleh variabel lain yang tidak termasuk dalam penelitian ini.

Standard (IFRS) memiliki nilai $\mathrm{t}_{\text {hitung }}$ sebesar 2,785 dan $t_{\text {tabel }}$ sebesar 1,943 maka ( $\left.t_{\text {hitung }}>t_{\text {tabel }}\right)$. Kemudian dari tingkat signifikan sebesar 0,039 lebih kecil dari 0,05 $(0,039<0,05)$. Hal ini berarti bahwa untuk variabel International Financial Reporting Standard (IFRS) $\left(\mathrm{X}_{1}\right)$ secara parsial memiliki pengaruh yang signifikan terhadap Timely Loss Recognition (TLR). Hal ini menunjukkan bahwa regulasi dan perangkat yang mendukung jalannya IFRS sudah berfungsi dengan baik di negara 
Indonesia. Dibuktikan dengan

beberapa perusahaan yang sudah menerapkan Standar Internasional pada sektor Trade and Service yang terdaftar pada Bursa Efek Indonesia, selain itu perusahaan juga terlihat siap untuk menghadapi perubahan standar akuntansi yang yang diterapkan pemerintah pada tahun 2012. Hasil penelitian ini juga mendukung beberapa penelitian terdahulu seperti Christensen et al. (2007), Barth et al. (2008), dan Chua et al. (2012) yang menemukan adanya pengaruh positif yang signifikan.

Merujuk pada penelitian yang dilakukan Pananen \& Lin (2009) mengatakan bahwa adanya penurunan kualitas akuntansi yang

\section{Pengaruh Kepemilikan Asing

terhadap Timely Loss
Recognition

Pada penelitian ini, peneliti menguji ada tidaknya pengaruh kepemilikan asing terhadap pengakuan rugi yang lebih tepat waktu. Peneliti menggunakan persentase kepemilikan dan keaslian dari persentase kepemilikan asing semakin menurun bukan dikarenakan adanya perusahaan yang menerapkan International Financial Reporting Standard (IFRS), tetapi karena adanya perubahan standar. Pemerintah Indonesia berkomitmen untuk menerapkan IFRS per 1 Januari 2012, sehingga memaksakan perusahaan untuk sudah menerapkan standar konvergensi IFRS per tahun 2012. Dengan demikian hal ini dibarengi dengan kesiapan perusahaan untuk memahami dan menerapkan standar yang baru. Pemahaman yang baik akhirnya membuat penerapan standar International Financial Reporting Standard (IFRS) semakin maksimal.

sebagai alat ukur. Berdasarkan hasil uji t pada tabel 4.8 diketahui bahwa variabel Kepemilikan Asing memiliki nilai $t_{\text {hitung }}$ sebesar $-1,930$ dan $t_{\text {tabel }}$ sebesar 1,943 maka (- $t_{\text {hitung }}$ $\left.<t_{\text {tabel }}\right)$. Kemudian dari tingkat signifikan sebesar 0,079 lebih besar dari $0,05(0,079>0,05)$. Hal ini berarti bahwa untuk variabel Kepemilikan Asing $\left(\mathrm{X}_{2}\right)$ secara parsial tidak memiliki pengaruh 
yang signifikan terhadap Timely

Loss Recognition (TLR). Penelitian

ini mengungkapkan adanya proses

legitimasi pada praktik atau aturan yang dianggap baik. Dengan masuknya investor asing, maka akan menambah keberadaan kepemilkan asing di indonesia yang telah diharapkan mampu memperbaiki kinerja perusahaan di negara Indonesia secara tidak langsung, sekaligus dapat mengarahkan pada kualitas informasi akuntansi yang

semakin baik dikarenakan perusahaan akan berfokus pada perpajakan, dividen dan kebijakan lainya yang dapat memberikan kepercayaan investor yang ingin menanamkan modalnya di perusahaan Trade and Service yang terdaftar di Bursa Efek Indonesia. Hasil penelitian ini juga tidak mendukung beberapa penelitian terdahulu seperti Christensen et al. (2007), Barth et al. (2008), dan
Chua et al. (2012) yang menemukan adanya pengaruh positif yang signifikan.

Keberadaan pemilik asing berdasarkan persentase tidak berpengaruh pada peningkatan pengakuan rugi yang semakin tepat waktu, begitu pula dengan keaslian dan keberadaan pemilik asing di jajaran manajemen perusahaan. Namun, manajemen akan menghindari pengakuan rugi yang besar di suatu periode dan memilih untuk meratakannya (smooth) di periode-periode berikutnya (Lang et al., 2006), yang berarti tingkat asimetri antara pengakuan rugi dan laba semakin kecil. Ball \& Shivakumar (2005) menyatakan bahwa perusahaan yang sangat berfokus pada perpajakan, dividen, dan kebijakan lainnya mengarahkan pada permintaan yang rendah pada informasi yang berkualitas, dalam hal ini pengakuan rugi yang lebih tepat waktu dibandingkan dengan pengakuan laba. 


\section{Variabel Kontrol}

Pada penelitian ini, peneliti menguji ada tidaknya pengaruh variabel kontrol. Berdasarkan hasil uji t pada tabel 4.8 diketahui bahwa Pada variabel kontrol Ukuran Perusahaan diperoleh $t_{\text {hitung }}$ sebesar $-1,585$ dan $t_{\text {tabel }}$ sebesar 1,943 serta nilai signifikan sebesar -061. Pada variabel kontrol Profitabilitas diperoleh $t_{\text {hitung }}$ sebesar 0,854 dan $t_{\text {tabel }}$ sebesar 1,943 serta nilai signifikan sebesar 070. Pada variabel kontrol Leverage diperoleh $t_{\text {hitung }}$ sebesar 1,960 dan $t_{\text {tabel }}$ sebesar 1,943 serta nilai signifikan sebesar 056 .

Sedangkan pada variabel kontrol Kualitas Audit diperoleh $t_{\text {hitung }}$ sebesar 0,730 dan $t_{\text {tabel }}$ sebesar 1,943 serta nilai signifikan sebesar 013.

\section{J. Kesimpulan}

\section{Berdasarkan}

hasil

pembahasan di bab sebelumnya, maka dapat diambil beberapa kesimpulan sebagai berikut :
1. Variabel

International

Financial Reporting Standard (IFRS) secara parsial memiliki pengaruh yang signifikan terhadap Timely Loss Recognition (TLR) pada perusahaan Trade and Service yang terdapat di Bursa Efek Indonesia (BEI) periode 20142016.

2. Variabel Kepemilikan Asing secara parsial tidak memiliki pengaruh yang signifikan terhadap Timely Loss Recognition (TLR) pada perusahaan Trade and Service yang terdapat di Bursa Efek Indonesia (BEI) periode 20142016.

3. Variabel

International

Financial Reporting Standard (IFRS) dan Kepemilikan Asing secara bersama-sama (simultan) memiliki pengaruh yang signifikan terhadap Timely Loss Recognition (TLR) pada perusahaan Trade and Service yang terdapat di Bursa Efek Indonesia (BEI) periode 2014-2016. 


\section{K. Keterbatasan Penelitian}

Peneliti menyadari bahwa terdapat beberapa keterbatasan dari penelitian ini yang mungkin menyebabkan hasil yang tidak konsisten, untuk itu dapat dijadikan perbaikan untuk penelitian selanjutnya. Beberapa keterbatasan tersebut adalah sebagai berikut :

1. Dalam penelitian ini, peneliti hanya menguji variabel Timely Loss Recognition (TLR) dengan LNEG yang berfokus pada pengakuan rugi yang besar oleh perusahaan, padahal indikator ketepatan waktu pengakuan rugi bisa dilihat tidak hanya dari pengakuan rugi yang besar, tetapi juga bisa terlihat dari indikator lain, seperti penerapan akuntansi berbasis akrual.

2. Peneliti menggunakan sampel periode tahun 20142016, dengan menggunakan cut off pada tahun 2016. Hal ini menjadikan variabel
Reporting Standard (IFRS) berpengaruh karena standar International Financial Reporting Standard (IFRS) diterapkan pada tahun 2012 sehingga terlihat adanya perubahan kualitas informasi akuntansi. Standar akuntansi diterapkan secara efektif karena penerapannya yang bertahap dari tahun ke tahun, sehingga terdapat kemungkinan bahwa seluruh standar berbasis International Financial Reporting Standard (IFRS) diterapkan oleh perusahaan sampai dengan mandatory full adoption di tahun 2016.

3. Pada variabel kepemilikan asing, terutama pada proksi keaslian, peneliti hanya menelusuri dengan kriteria yang telah ditentukan dan tidak sampai pada ultimate ownership. Padahal dengan tidak dilakukannya penelusuran sampai dengan ultimate ownership akan 
membuat judgment peneliti

mengenai keaslian pemilik

asing menjadi lemah. Hal ini

karena

terdapat

kemungkinan

bahwa

ultimate owner memang

benar-benar orang atau

organisasi asing. Penelusuran

tidak dilakukan karena

sumber yang resmi sulit

diperoleh. Walaupun

terdapat kewajiban untuk mengungkapkan pemegang saham perusahaan sampai pada tingkat individu, seperti yang tertuang dalam Keputusan Ketua Bapepam dan LK Nomor Kep431/BL/2012 tentang Penyampaian Laporan

Tahunan Emiten atau Perusahaan Publik, banyak perusahaan yang tidak mematuhinya dan tidak mengungkapkan pemilik saham akhirnya dalam Annual Report. Akibatnya penelusuran pemegang saham akhir pun tidak dapat dilakukan.
4. Terdapat kemungkinan bahwa pemilik yang berbasis di Tax Haven Country tersebut adalah benar-benar orang atau organisasi asing. Hasil penelitian pun akhirnya menjadi bias dan menunjukkan pengaruh yang tidak signifikan.

\section{Saran}

Berdasarkan kesimpulan dan keterbatasan penelitian yang diungkapkan sebelumnya, peneliti memberikan beberapa saran untuk penelitian selanjutnya, yaitu sebagai berikut

1. Penelitian selanjutnya pada variabel Timely Loss Recognition (TLR), peneliti dapat menggunakan alat ukur lain seperti Accrual-based test untuk melakukan pengujian lebih lanjut.

2. Apabila melakukan penelitian mengenai kualitas informasi akuntansi setelah konvergensi International

Financial Reporting Standard (IFRS), 


$$
\begin{array}{lr}
\text { peneliti } & \text { sebaiknya } \\
\text { menggunakan } & \text { sampel } \\
\text { perusahaan diatas tahun } 2014 . \\
\text { Selain regulasi yang lebih } \\
\text { matang, infrastruktur } \\
\text { pendukung penerapan standar } \\
\text { yang baru juga diperkirakan } \\
\text { telah mendukung sehingga } \\
\text { kualitas laporan keuangan } \\
\text { yang dihasilkan perusahaan } \\
\text { menjadi lebih baik. }
\end{array}
$$

3. Pada variabel Kepemilikan Asing, peneliti dapat melakukan penelitian tingkat keaslian pemilik asing sampai pada ultimate ownership di perusahaan melalui sumber yang lebih resmi, misalnya akta notaris atau pemegang saham deviden perusahaan sehingga hasil penelitian dapat lebih relevan.

\section{DAFTAR PUSTAKA}

Aflatooni, A., \& Mokarami, M. (2013). Real Earnings Management and Timely Loss Recognition. Research Journal of Recent Sciences. Vol. 2 (12),
28-37, December (2013) ISSN 2277-2502.

Agus Sartono. (2010). Manajemen Keuangan Teori dan Aplikasi. Edisi 4. Yogyakarta : BPFE

Anggito Abimanyu (2017). Fenomena Modal Masuk Asing. http://ekonomi.kompas.com

Annisa Nursyamsi (2017). Pelaporan dan Pengungkapan Laporan Keuangan alfabeta.

Arum, E. D. (2013). Implementation of International Financial Reporting Standards (IFRS) and the Quality of Financial Statement Information in Indonesia. Research Journal of Finance and Accounting. Vol.4, No.19, 2013. ISSN 2222-1697 (Paper) ISSN 2222-2847.

Ball, R., \& Shivakumar, L. (2005). Earnings Quality in U.K. Private Firms: Comparative Loss Recognition Timeliness. Journal of Accounting and Economics. JEL classifications: M41; M44; M47; G24; G29; G33; G34; G38; K22.

Ball, R., Kothari, S. P., \& Robin, A. (2000). The Effect of 
International Institutional

Factors on Properties of

Accounting Earnings. Journal

of Accounting and Economics.

Received 3 August 1998; received in revised form 9 June 2000.

Barth, M. E., Landsman, W. R., \& Lang, M. H. (2008). International Accounting Standards and Accounting Quality. Journal of Accounting Research. Vol. 46, Issue 3 June 2008.

Basu, S., Hwang, L.-S., \& Jan, C.-L. (2009). Differences in Conservatism between Big Eight and Non-Big Eight Auditors. Working Paper, Temple University, Seoul National University, and California State University. Vol. 15 No. 2, June 2009.

Chua, Y. L., Cheong, C. S., \& Gould, G. (2012). The Impact of Mandatory IFRS Adoption on Accounting Quality: Evidence from Australia. Journal of International Accounting Research. Vol. 11, No. 1, pp.
Chariri dan Kusuma (2010). Analisis

Kualitas Informasi Akuntansi

Sebelum Dan Sesudah Adopsi

Penuh International Financial

Reporting Standard (IFRS).

Proceedings SNEB 2014.

Cohen, D. A. (2003). Quality of Financial Reporting Choice: Determinants and Economic Consequence. Working Paper, Nortwestern University. Vol. 10 Issue. 21 ISSN.422581 London Business School Accounting Symposium.

DeFond, M., Hu, X., Hung, M., \& Li, S. (2011). The Impact of Mandatory IFRS Adoption on Foreign Mutual Fund Ownership: The Role of Comparability. Journal of Accounting and Economics. Vol. 51, (3), 2011. ISSN 01654101.

DiMaggio, P. J., \& Powell, W. W. (1983). The Iron Cage Revisited: Institutional Isomorphism and Collective Rationality in Organizational Fields. American sociological 
review. Vol. 48, Issue. 2 (Apr, 1983).

Djati, B. P. (2012). Analisis Laporan Keuangan. Yogyakarta: Pusat Penerbitan Akademi Akuntansi YKPN 2012 www.Akademi_Akuntansi_YKP N.com

Eisenhardt, K. M. (1989). Agency Theory: An Assesment and Review. Academy of Management Review. Vol. 14, No.

http://www.jstor.org/stable/258 191.

Fahmi. (2013). Pengaruh Rasio Leverage, Rasio Intensitas Modal dan Pangsa Pasar Terhadap Kinerja Keuangan. eJurnal Kewirausahan. Vol. 3 Issue 2 : 2009

Fanani, Z. (2009). Kualitas Pelaporan Keuangan: Berbagai Faktor Penentu Konsekuensi Ekonomis. Jurnal Akuntansi dan Keuangan Indonesia. Vol. 6 - No. 1, Juni 2009.

Francis, J. R., \& Wang, D. (2008). The Joint Effect of Investor Protection and Big 4 Audits on
Earnings Quality Around the World. Contemporary Accounting Research. Vol. 25 No. 1.

Ghozali, I. (2013). Aplikasi Analisis Multivariate dengan Program IBM SPSS 18. Semarang: Badan Penerbit Universitas Diponegoro.

Global Forum on Transparency and Exchange of Information for Tax Purposes (2013).; Report on Progress. Paris: OECD. http://www.oecd.org/tax/transp arency/ Tax Transparancy 2013

Hill, C. W., \& Jones, T. M. (1992). Stakeholder-Agency Theory. Journal of Management Studies. Vol 29, Issue 2

Ilham Kurniawan. (2012). Model Regresi Dengan Variabel Bebas Dummy.

http://blog.unnes.ac.id/aiomcik/ 2015/10/12/ekonometrika-

variabel dummy/.

Indonesian Capital Market Directory 2011. Jakarta: ECFIN Institute for Economic and Financial Research. www.ecfin.co.id Kane, Velury, Simanjuntak. (2008). Pengaruh Time Budget Pressure 
Dan Resiko Kesalahan

Terhadap Penurunan Kualitas

Audit (Reduced Audit Qaulity)

(Studi Empiris pada Auditor KAP di Jakarta).

Kartikagaby.(2014). Konvergensi

Akuntansi International.

https://kartikagaby.wordpress.c

om. 12014/06/12/konvergensi-

akuntansi-international/

Lababa.(2008). Statistika Ekonomi I

Skala Pengukuran.

https://.wordpress.com

/2013/09/10/skala-pengukuran/.

Lang, M., Raedy, J. S., \& Wilson, W.

(2006). Earnings Management

and Cross Listing: Are

Reconciled Earnings

Comparable to US Earnings?

Journal of Accounting and

Economics. Vol. 42, issue 1-2.

Lembaran Negara Republik

Indonesia, (1999). Daftar

Bidang Usaha Yang Tertutup

Dan Bidang Usaha yang

Terbuka Dengan Persyaratan Di

Bidang Penanaman Modal.

Leonardo Gustav Primadi (2016 :

180) Sejarah Perkembangan

Akuntansi di Indonesia. https://leonardogustav.wordpre

ss.com /2016/06/06/sejarah-

perkembangan-standar-

akuntansi-di-indonesia/.

Mamduh M Hanafi. (2010). Analisis Laporan Keuangan Edisi Ke Empat.

https://www.tokobukurahma.co m/analisis-laporan-keuangan-

edisi-ke-empat mamduh-mhanafil.

Nursalam. (2003). Konsep dan Penerapan Metodologi Penelitian Ilmu Keperawatan Pedoman Skripsi, Tesis, dan Instrumen Penelitian Keperawatan, Jakarta : Salemba. http://Pendekatan Praktis Edisi 3/NursalamJakarta: Salemba Medika, 2003.

Outa, E. R. (2011). The Impact of International Financial Repoting Standards (IFRS) Adoption on Accounting Quality of Listed Companies in Kenya. International Journal of Accounting and Financial Reporting. 2011, Vol. 1, No. 1. 
Paglietti, P. (2009). Earnings Management, Timely Loss Recognition and Value Relevance in Europe Following the IFRS Mandatory Adoption: Evidence from Italian Listed Companies. International Business Review. Vol. 4, No. 23 ISSN. 1826-4719.

Peraturan Menteri Negara Badan Usaha Milik Negara Nomor : (Per - 01/Mbu/2011) Tentang Penerapan Tata Kelola Perusahaan yang Baik (Good Corporate Governance) Pada Badan Usaha Milik Negara.

Peraturan Otoritas Jasa Keuangan

Nomor (55 /POJK.03/2016)

Tentang Penerapan Tata Kelola

Bagi Bank Umum.

Prasetya, F. D. (2012). Perkembangan

Standar Akuntansi Keuangan di Indonesia. Jurnal Ilmiah Mahasiswa Akuntansi. Vol. 1, No. 4, Juli 2012.

Putri. (2011). Pengaruh Kepemilikan

Manajerial, Kepemilikan Asing,

Dan Kepemilikan Institusional Terhadap Kecenderungan Pemilihan Auditor Berkualitas
(Studi Empiris pada Perusahaan Manufaktur yang Terdaftar di Bursa Efek Indonesia Tahun 2009-2012).

Rudy Suryanto, (2014). Standards sesuai dengan Surat Edaran Kementrian BUMN No S156/D4.MBU/2010.

dailyrudy.wordpress.com

Sekaran,U. (2011). Research Methods for Business: Metodologi Penelitian untuk Bisnis. Jakarta: Salemba Empat. ISSBN. 9796913151.

Setiyadi. (2009). Analisis Pengaruh Profitabilitas, Struktur Aktiva, Time Interest Earned, Tingkat Pertumbuhan, Dan Ukuran Perusahaan Terhadap Struktur Modal ( Studi Pada Perusahaan Manufaktur yang Terdaftar di Bursa Efek Indonesia Tahun 2009-2013)

Sianipar, G. A., \& Marsono. (2013). Analisis Komparasi Kualitas Informasi Akuntansi Sebelum dan Sesudah Pengadopsian Penuh IFRS di Indonesia. Diponegoro Journal of 
Accounting. Vol. 2, No 3, Tahun 2013.

Simerly \& Li, dalam Fauzi. (2006).

Pengaruh Struktur Kepemilikan

Terhadap Profitabilitas

Perusahaan Manufaktur di

Indonesia. Vol. 15, No. ISSN. 1, 2338-8137.

Sugiyono. (2013). Metode Penelitian

Kuantitatif, Kualitatif dan

Kombinasi (Mixed Methods).

Alfabeta : Anggota Ikatan

Penerbit Indonesia (IKAPI).

Suprihatin dan Tresnaningsih (2013).

Suprihatin.

Pengaruh

Konvergensi International

Financial Reporting Standard

terhadap Relevansi Nilai

informasi Akuntansi (Studi
Empiris Pada Perusahaan

Manufaktur di Bursa Efek Indonesia).

http://lib.ui.ac.id/naskahringkas /2013-03/S46668-Siti\%20.

Wahana. (2010). Penarikan Sampel secara Numerik. https://www.academia. Vol.5, No.2, Maret 2010.

Wahyuni, E. T. (2012). Panduan Praktis Standar Akuntansi Keuangan. Jakarta : Edisi 2 Salemba Empat.

Zeghal et al. (2015). Emerging Markets Queries in Finance and Business, Measuring the effects of IFRS adoption on accounting quality: a review. Vol. 32 ISSN. 2212-5671. 